\title{
Consumo, identidade e publicidade: uma relação a ser (re)pensada*
}

Diana Gualberto de Macedo

Pesquisadora. Mestra em Comunicação e Práticas de Consumo pela Escola Superior de Propaganda e Marketing de São Paulo (ESPM).

E-mail: dianagmacedo@hotmail.com

Resumo: A crítica aborda, através da publicidade da cerveja Skol, com o filme Argentinos do samba, o tema da construção de identidades, mais especificamente da identidade nacional, relacionando a discussão sobre publicidade ao processo do consumo. É demonstrado como o consumo é indispensável ao processo de produção, motor da dinâmica da sociedade. A publicidade, inserida na cultura midiática, dá velocidade ao processo do consumo, ou seja, a mercadoria é produzida e a publicidade tem o papel de divulgá-la para ser consumida, associando sua funcionalidade (valor de uso) aos seus valores simbólicos (valor de troca). E, dessa forma, a publicidade possibilita, através de imagens e discursos, a circulação de comportamentos identitários, associados a estilos de vida.

Palavras-chave: consumo, identidade, identidade nacional, mídia, publicidade.
Abstract: The critique, through the Skol beer advertising, with the film Argentinos do samba, discuss the theme of identity construction, specifically the national identity, relating the discussion about advertising, with the process of consumption. It is demonstrated how the consumption is essential to the production process, engine of the society dynamic. The advertising, inserted in media culture, gives speed to the process of consumption, which means, the good is produced and the advertising's role is to publicize it to be consumed, associating its functionality (use value) to its symbolic values (exchange value). And so, the advertising makes possible, by images and discourses, the circulation of identity behaviors, associated with lifestyles.

Keywords: consumption, identity, national identity, media, advertising.

Neste trabalho a crítica a ser feita terá como pilar a construção da identidade a partir da cultura da mídia e também da cultura do consumo, isso porque elas são culturas hegemônicas e merecedoras de destaque na sociedade contemporânea. De qualquer forma, vale destacar que não são as únicas que participam desse processo. Para tanto, escolhemos um filme para publicidade da cerveja Skol, Argentinos do samba, veiculado durante o período que antecedeu a Copa do Mundo de 2010, para aproveitar, justamente, a rivalidade futebolística entre Brasil e Argentina.

Antes de falarmos mais especificamente sobre a relação da publicidade com a construção da identidade, abordaremos a relação entre consumo e publicidade de forma mais ampla.

${ }^{*}$ A pesquisa, da qual este trabalho é parte, está vinculada à dissertação de mestrado defendida na ESPM e intitulada: "Comunicação, recepção e consumo: inter-relações. O receptor/consumidor no prime time brasileiro e português", parte do projeto integrado Universidade de Coimbra-ESPM, com orientação da profa. Dra. Maria Aparecida Baccega. 
1. CASTRO, Gisela. Mídia, consumo, globalização e contemporaneidade. In: BACCEGA, Maria Aparecida. (Org.). Comunicação e culturas do consumo. São Paulo: Atlas, 2008. p. 139

2. ROCHA, Everardo P. Guimarães. Culpa e prazer: imagens do consumo na cultura de massa. Comunicação, mídia e consumo, São Paulo, v. 2, n. 3, p. 137, mar. 2005.

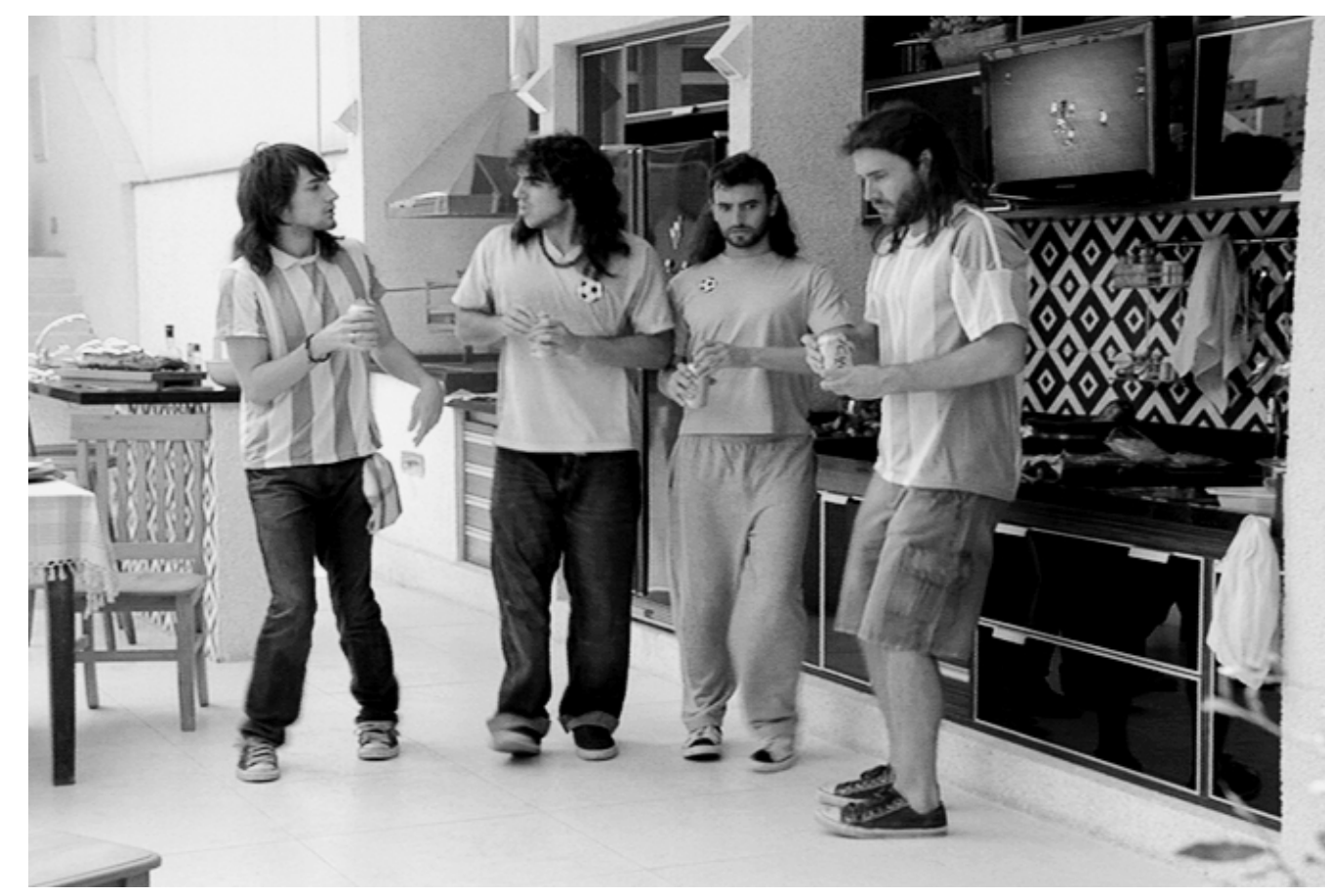

Torcedores argentinos experimentam uma cerveja de nacionalidade brasileira e sofrem uma "inesperada" reação.

E por que, aqui, falar do consumo e da publicidade? A publicidade está estreitamente ligada à produção, sendo assim, ela é importante para o escoamento da produção, ou melhor, para dar velocidade a esse processo. E esse escoamento, por sua vez, só é possível, é claro, através do consumo. Vamos discutir agora, a partir desse olhar para a publicidade, sua relevância na contemporaneidade.

Castro, de forma clara, explica que a passagem ao capitalismo pós-industrial acarretou a imaterialidade das marcas e criou outras intangíveis, ao contrário do capitalismo industrial, em que a importância maior era dada à produção material.

Mais uma vez os pilares publicidade e marketing entram em cena, buscando moldar de forma favorável a percepção da imagem através da qual uma marca venha a ser reconhecida e valorizada. Se antes se vendiam coisas, atualmente se vendem, sobretudo, imagens e modos de ser. Verifica-se um investimento mais sutil do mercado nos próprios processos de subjetivação. Nesse sentido, a mídia desempenha uma função primordial ao veicular e induzir ideias, atitudes e padrões de comportamento que podem servir de modelo para a construção de identidades em nossos dias ${ }^{1}$.

Sabe-se que a publicidade não leva diretamente à compra. Como explicita Everardo Rocha, "a cultura de massa - mídia, marketing, publicidade - interpreta a produção, socializa para o consumo e nos oferece um sistema classificatório que permite ligar um produto a cada outro e todos juntos às nossas experiências de vida" ${ }^{2}$. De qualquer forma, ao direcionarmos nosso olhar para a cultura, podemos perceber que, independentemente do contato físico com as 
mercadorias (seu uso, seu consumo), elas podem comunicar de outra forma. O falar sobre elas já é uma forma de consumo e permite que experiências sejam compartilhadas. Em outras palavras, o papel da cultura de massa, na qual a publicidade se insere, não se esgota no consumo material dos bens, uma vez que os produtos e serviços podem ser objetos de discussões sociais - a favor ou contra eles e de outros diálogos que provocam.

A publicidade, bem como a mídia em geral, de uma forma ou de outra, encontram uma maneira de mexer com os anseios, necessidades, desejos, gostos, ideais, estilos de vida e vontade de compartilhar determinadas visões de mundo e experiências dos sujeitos. Além disso, há uma punição para o não consumo. Convivemos com a exclusão social, com um modo específico de comportar-se, de vestir-se para frequentar determinados lugares etc. É interessante aqui retomarmos a questão do sujeito como mercadoria (Bauman), sobre essa necessidade de os próprios sujeitos se transformarem em mercadorias vendáveis. Segue um trecho do livro do autor, que nos ilumina nessas reflexões:

Bombardeados de todos os lados por sugestões de que precisam se equipar com um ou outro produto fornecido pelas lojas se quiserem ter a capacidade de alcançar e manter a posição social que desejam, desempenhar suas obrigações sociais e proteger a autoestima - assim como serem vistos e reconhecidos por fazerem tudo isso -, consumidores de ambos os sexos, todas as idades e posições sociais irão sentir-se inadequados, deficientes e abaixo do padrão, a não ser que respondam com prontidão a esses apelos ${ }^{3}$.

$\mathrm{E}$, para isso, a publicidade não precisa se utilizar de nenhuma força física; ela exerce o poder de persuasão. O que entra em jogo, muito mais do que a utilidade e a funcionalidade dos produtos e/ou serviços (valor de uso), são os valores simbólicos (valor de troca). Podemos aqui fazer uma relação com a sociedade de controle descrita por Deleuze. Para o autor, o poder exercido através do controle é contínuo e ilimitado, porém de curto prazo, de forma fluida, ou seja, sem a utilização de força física. É o caso do poder de persuasão da publicidade. Essa sociedade descrita pelo autor difere das sociedades disciplinares descritas por Foucault, em que a disciplina respeitava uma lógica geométrica, progressiva, de longa duração ${ }^{4}$.

De forma análoga à ideia da sociedade de controle, Burrowes constata que "as pessoas estão engajadas nesse campo [campo social] e não propriamente enganadas. O poder não é exercido por um grupo ou uma instância privile-

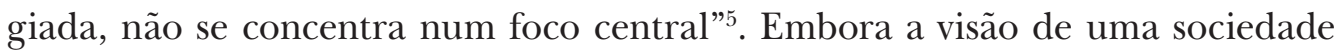
de controle (Deleuze) seja a mais adequada, para a autora a visão de poder mais pertinente seria a de Foucault, do poder fragmentado e distribuído em microrrelações. Ou seja, o que a mídia e a publicidade, mais especificamente, exercem é o poder de persuasão, que pode parecer uma coerção disfarçada, justamente por aquilo que vimos antes, sobre o medo da inadequação, do não pertencimento.

Apesar do senso comum, sabe-se que a publicidade nem sempre manipula, na forma pejorativa da palavra (sinônimo de enganação), mas motiva, influencia,
3. BAUMAN, Zygmunt Vida para consumo: a transformação das pessoas em mercadorias. Rio de Janeiro: Jorge Zahar Ed., 2008. p. 74.

4. DELEUZE, Gilles. Conversações. Rio de Janeiro: Ed. 34, 1992

5. BURROWES, Patrícia. Prontoparaoconsumo. In: CAIAFA, J.; ELLAJJI, M (Org.). Comunicação e sociabilidade: cenários contemporâneos. Rio de Janeiro: MauadX, 2007. p. 99. 
6. CARRASCOZA, João Anzanello. Publicidade: o sonho do consumo e a realidade da produção. In: BACCEGA, Maria Aparecida (Org.). Comunicação e culturas do consumo. São Paulo: Atlas, 2008. p. 218

7. OROFINO, Maria Isabel. Mediações na produção de TV: um estudo sobre O Auto da Compadecida. Porto Alegre: EDIPUCRS, 2006. p. 184

8. QUESSADA, Dominique. $O$ poder da publicidade na sociedade consumida pelas marcas: como a globalização impõe produtos, sonhos e ilusões. São Paulo: Futura, 2003. p. 78.

9. BOURDIEU, Pierre. Questões de sociologia. Rio de Janeiro: Marco Zero, 1983. p. 90-91.

10. FOUCAULT, Michel. $A$ verdade e as formas jurídicas. 3. ed. Rio de Janeiro: NAU, 2003. p. 14. isto é, desencadeia pensamentos, ideias, que podem proporcionar prazer através das representações dos produtos. E essas representações, sim, poderão acarretar a compra de bens, pois são capazes de interferir diretamente na subjetividade, e isso nada mais é do que o hedonismo autoilusivo a que Campbell se refere, isto é, que os prazeres não vêm somente de experiências concretas, vividas, mas da imaginação, que não deixa de ser uma forma de experiência. Portanto, independentemente de a publicidade acarretar ou não a compra dos produtos, o fato de entrarmos em contato com ela já é uma forma de consumo, em que estamos consumindo não bens tangíveis, mas intangíveis. Isso é fundamental para a constituição do homem como sujeito e, por sua vez, pode acarretar o consumo de bens tangíveis.

Novos produtos surgem a todo o momento e as marcas desses certamente são importantes; contudo, é interessante notar que as pessoas podem não possuir o celular " $\mathrm{X}$ " anunciado na televisão, ou que não compram o tempero "Y", nem o creme dental "Z", mas elas têm celulares, usam temperos e cremes dentais. Segundo Carrascoza, "o discurso persuasivo da publicidade não visa tanto à compulsão pela compra, mas à adesão do consumidor ao consenso

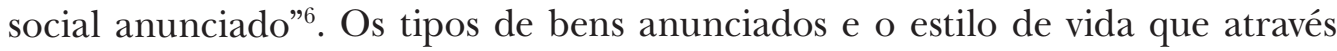
deles é proposto se tornam públicos principalmente através da publicidade. E, muitas vezes, acabamos consumindo bens materiais para nos sentirmos incluídos e parte integrante da sociedade de consumo.

Vale ressaltar que nem toda publicidade é homogênea. Existem publicidades que não seguem o padrão hegemônico midiático, havendo mediações na produção. Segundo Maria Isabel Orofino, a produção "é de fato realizada por pessoas e nem todas abrem mão de seus valores e ideais simplesmente por estarem atuando na indústria [...]"7. Fala-se muito sobre as mediações no âmbito da recepção, mas não devemos esquecer que o mesmo sujeito que consome também trabalha, ou seja, é receptor/consumidor e produtor ao mesmo tempo, e carrega consigo suas mediações.

Além de anunciar produtos/serviços, a publicidade ajuda a construir a subjetividade e, consequentemente, as identidades. Mas o que procuramos ressaltar aqui é que ela não é a única capaz disso. Afinal, a sociedade toda pode ser concebida como mídia (Quessada) ${ }^{8}$. O discurso publicitário exerce influência sobre os sujeitos bem como outros discursos, dos mais diversos campos: jornalístico, jurídico, acadêmico, artístico, religioso etc. É, de certa forma, previsível e até mesmo evidente que cada um desses campos buscará a satisfação de seus objetivos, e que os emissores tentarão manter e/ou conquistar poder e prestígio para o seu campo (Bourdieu) ${ }^{9}$.

Todo tipo de conhecimento é inventado - "o conhecimento não está em absoluto inscrito na natureza humana" ${ }^{10}$, segundo Foucault. Devido a isso, não deveríamos acreditar, por exemplo, que o telejornal sempre transmite a verdade, relata apenas fatos, e que portanto merece credibilidade. Imaginemos que de 100 notícias possíveis, o jornalista escolha 10, e justamente que falam de violência. É evidente que as pessoas vão pensar que o mundo está cada 
vez mais violento, que é perigoso sair de casa à noite etc. Mas pode ser que as outras 90 notícias nem falassem sobre violência, mas, como não foram ao ar, dificilmente as pessoas ficarão sabendo. Ou seja, o telejornal constrói um mundo editado e, dessa forma, pode influenciar também o comportamento das pessoas, atuando na subjetividade delas. Como já visto, a sociedade como um todo é uma grande mídia; a diferença, como bem nos aponta Tavares ${ }^{11}$, está no grau de consciência quanto aos recursos utilizados, isto é, uns mais e outros menos perceptíveis.

Ao recebermos qualquer discurso ou mensagem nós os interpretamos, e devemos partir da premissa de que o emissor está nos mostrando o que para ele é mais importante. Em outras palavras, é essencial levarmos em consideração o lugar de fala, isto é, a posição social do emissor, evitando dessa forma a posição radical ante determinados campos de conhecimento.

A mídia em geral e de forma específica a publicidade oferecem modelos de identificação, como afirma Kellner. "É a cultura da mídia que cada vez mais fornece material e recursos para a constituição das identidades." ${ }^{2}$ Falamos aqui em constituição, porque elas não são descobertas, mas sim construídas a partir das práticas cotidianas. Além disso, devem ser reconhecidas (Bauman), assim como os bens de consumo (Canclini), para que compartilhem sentidos:

Quando se trata de pertencer a uma classe, é necessário provar pelos próprios atos, pela "vida inteira" - não apenas exibindo ostensivamente uma certidão de nascimento -, que de fato se faz parte da classe a que se afirma pertencer. Deixando de fornecer essa prova convincente, pode-se perder a qualificação de classe, tornar-se déclassés ${ }^{13}$ (grifo nosso).

E essa prova de pertencimento não se restringe a uma classe socioeconômica, ela também deve servir para a inclusão em grupos específicos, para facilitar a identificação do estilo de vida dos sujeitos, da nacionalidade dos sujeitos, como veremos a seguir. Para Bauman ${ }^{14}$, a própria questão da identidade passou a ser discutida a partir do momento que começou a existir a crise do pertencimento, intensificada pela globalização.

Tornamo-nos conscientes de que o "pertencimento" e a "identidade" não têm a solidez de uma rocha, não são garantidos para toda a vida, são bastante negociáveis e revogáveis, e de que as decisões que o próprio indivíduo toma, os caminhos que percorre, a maneira como age - e a determinação de se manter firme a tudo isso - são fatores cruciais tanto para o "pertencimento" quanto para a "identidade"15.

Sendo assim, os sujeitos constroem suas identidades, seja para pertencerem a um determinado grupo, seja para serem reconhecidos. E a mídia, como um agente de socialização importante, ajuda a conformarmos nossa visão de mundo e estilo de vida. Decorre daí seu papel fundamental enquanto formadora de identidades. Não que ela imponha aos indivíduos algo, mas apenas oferece comportamentos identitários possíveis, como se atrás da tela - no caso da televisão - circulassem, além de mercadorias e sujeitos, modelos identitários com
11. TAVARES, Fred. Discurso publicitário e consumo: uma análise crítica. Rio de Janeiro: E-papers Serviços Editoriais Ltda., 2005. p. 11.

12. KELLNER, Douglas. A cultura da mídia - estudos culturais: identidade e política entre o moderno e o pós-moderno. Bauru, SP: Edusc, 2001. p. 333.

13. Ibid., p. 56.

14. BAUMAN, op. cit. 15. KELLNER, op. cit. p. 17. 
os quais os receptores/consumidores podem se identificar. Segundo Kellner, "as narrativas e as imagens veiculadas pela mídia fornecem os símbolos, os mitos e os recursos que ajudam a constituir uma cultura comum [...]"16.

Para finalizar, faremos agora a análise de um filme publicitário da cerveja Skol (Ambev), veiculado a partir de abril de 2010. O nome do filme é Argentinos do samba (agência: F/Nazca Saatchi \& Saatchi, direção de Clovis Mello e criação de Fabio Fernandes), e faz parte da campanha "Qualquer torcida fica redonda". Como já citado, a peça foi veiculada durante o período que antecedeu a Copa do Mundo e aproveitou, justamente, a rivalidade futebolística entre Brasil e Argentina. Conta a história de um grupo de torcedores argentinos que, após abrir uma lata de Skol, começa a se comportar do "jeito brasileiro".

Argentino 1: Cerveza, cervezita tengo.

Argentino 2: Que es esto?

Argentino 1: Una cerveza importada de Brasil, Skol.

Argentino 3: Que pasa?

Argentino 1: Samba?

Argentino 2: Samba!!

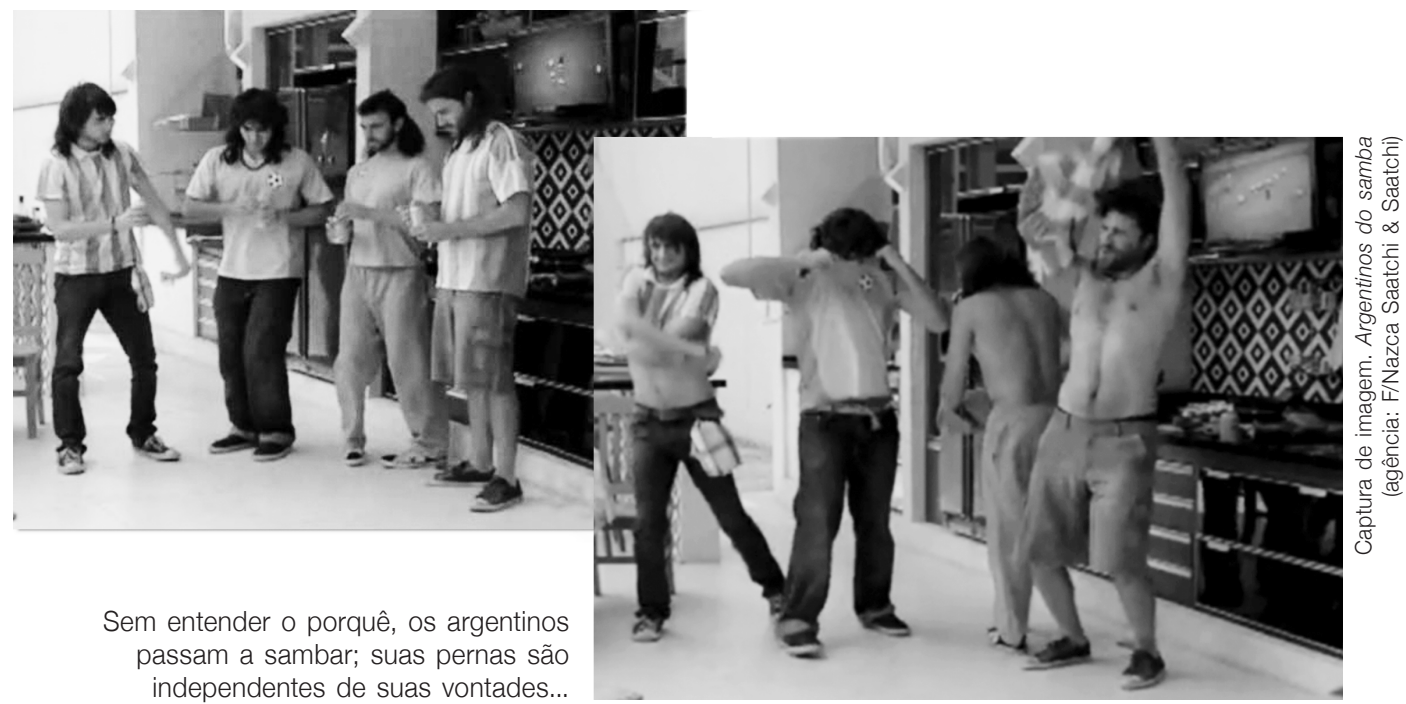

Argentino 3: Y su camisa? Es de Argentina?

E todos tiram as camisas da seleção da Argentina, apavorados.

Todos: Es de Argetinaaaa!!!

Argentino 2: Que es eso? Pelo?

E eles cortam os cabelos.

Todos: Son pelos argentinos, corta, corta...

Argentino 3: $\mathrm{Y}$ viva o Brasil!!

Argentino 1: El mejor fútbol del mundo...

Argentino 4: La mejor cerveza del mundo...

Todos: Skolll !!!!! 


\section{Consumo, identidade e publicidade - Diana Gualberto de Macedo}

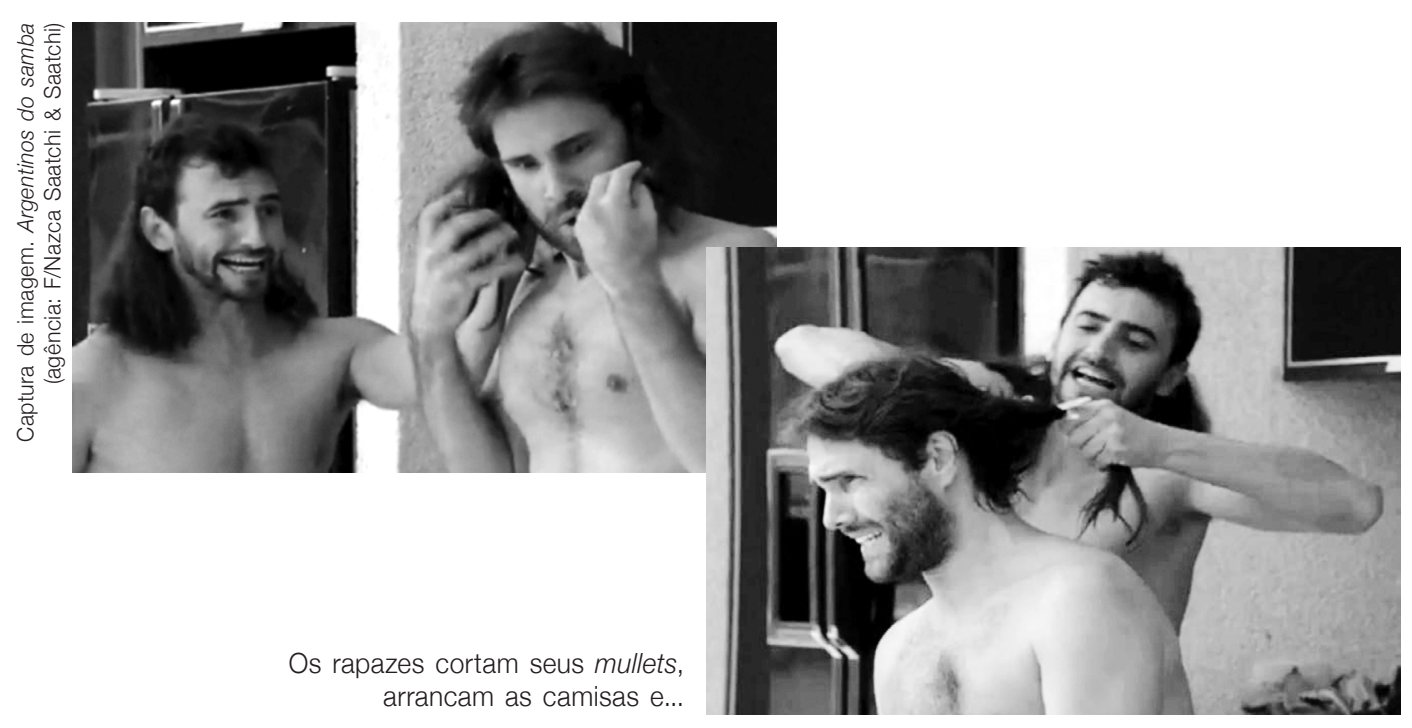

Argentino 5 chega ao lugar com a camisa da Argentina e pergunta aos outros:

Argentino 5: Gol? Gol de Argentina?

Os amigos o mandam embora.

Argentino 3: Ihhh, sai fuera bundón...

Locução em off: "Skol, qualquer torcida fica redonda. Se dirigir, não beba."

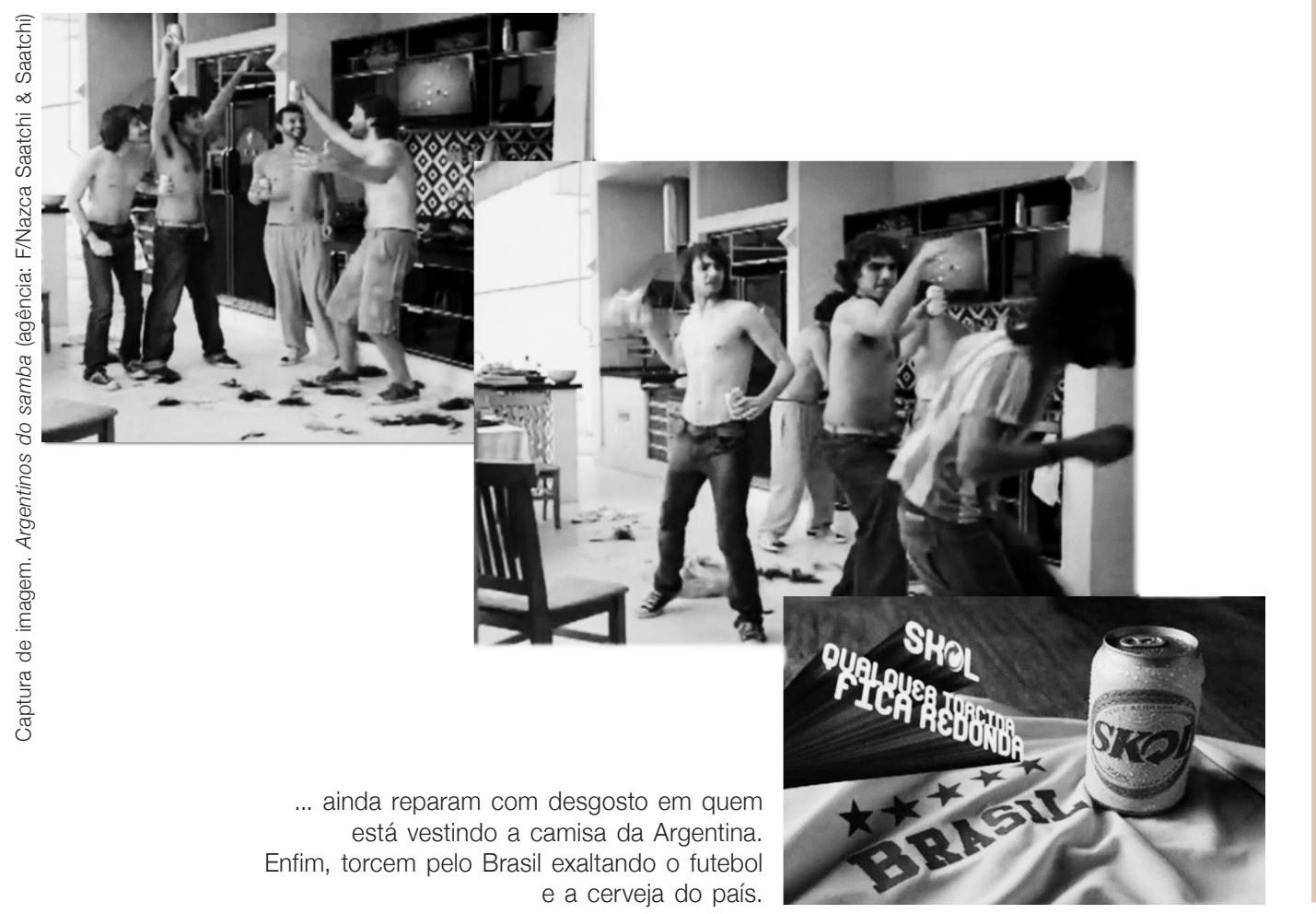


comunicação \& educação • Ano XV • número 3 • set/dez 2010

17. LIPPMANN, Walter. Estereótipos. In: STEINBERG, Ch. (Org.). Meios de comunicação de massa. São Paulo: Cultrix 1972. p. 157.
Trouxemos esse filme para continuar nossa crítica, refletindo sobre a publicidade no âmbito da cultura da mídia e do consumo, especificamente na sua relação com a construção das identidades. Aqui, particularmente, falaremos sobre identidade nacional. Aproveitando a rivalidade entre Brasil e Argentina no futebol, utilizando-se do humor, o filme publicitário mostra alguns estereótipos, tanto da Argentina (cabelos longos, camisa argentina) quanto do Brasil (samba, cerveja), e ambos, claro, envolvidos com um futebol conhecido por todo o mundo como de excelência. Certamente, a mídia intensifica a disseminação desses estereótipos, que, apesar de limitarem nossa visão de mundo, nos ajudam a organizar fatos, ideias e discursos e, assim, facilitam nossa interpretação. Verificamos, através desse filme, por exemplo, que samba faz-nos pensar no Brasil e pelos largos - cabelos compridos -, na Argentina.

De acordo com Lippmann, "o abandono de todos os estereótipos por um enfoque totalmente ingênuo da experiência empobreceria a vida humana"17. Não é que todos os argentinos tenham cabelo comprido nem o samba seja o único ritmo musical brasileiro, ou do qual mais gostamos, mas essas palavras, esses discursos e até mesmo imagens se perpetuam no imaginário dos sujeitos como algo que identifica esses países.

Vimos no decorrer do texto a relevância da cultura da mídia, principalmente a partir da publicidade, na construção das identidades e, especificamente no final do texto, com o filme publicitário Argentinos do samba, na construção da identidade nacional - argentina e brasileira -, através da utilização de alguns estereótipos que nos ajudam a interpretar o mundo e, por isso, nem sempre devem ser vistos apenas como algo negativo. Com isso, esperamos com este artigo ter contribuído para as reflexões sobre publicidade, consumo e identidade no campo da comunicação/educação.

\section{REFERÊNCIAS BIBLIOGRÁFICAS}

BAUMAN, Zygmunt. Vida para consumo: a transformação das pessoas em mercadorias. Rio de Janeiro: Jorge Zahar, 2008.

BOURDIEU, Pierre. Questões de sociologia. Rio de Janeiro: Marco Zero, 1983.

BURROWES, Patrícia. Prontoparaoconsumo. In: CAIAFA, J.; ELLAJJI, M. (Org.). Comunicação e sociabilidade: cenários contemporâneos. Rio de Janeiro: MauadX, 2007.

CARRASCOZA, João Anzanello. Publicidade: o sonho do consumo e a realidade da produção. In: BACCEGA, Maria Aparecida (Org.). Comunicação e culturas do consumo. São Paulo: Atlas, 2008.

CASTRO, Gisela. Mídia, consumo, globalização e contemporaneidade. In: BACCEGA, Maria Aparecida (Org.). Comunicação e culturas do consumo. São Paulo: Atlas, 2008.

DELEUZE, Gilles. Conversações. Rio de Janeiro: Ed. 34, 1992. 
Consumo, identidade e publicidade - Diana Gualberto de Macedo

FOUCAULT, Michel. A verdade e as formas jurídicas. 3. ed. Rio de Janeiro: NAU, 2003.

KELLNER, Douglas. A cultura da mídia - estudos culturais: identidade e política entre o moderno e o pós-moderno. Bauru, SP: Edusc, 2001.

LIPPMANN, Walter. Estereótipos. In: STEINBERG, Ch. (Org.). Meios de comunicação de massa. São Paulo: Cultrix, 1972.

OROFINO, Maria Isabel. Mediações na produção de TV: um estudo sobre O Auto da Compadecida. Porto Alegre: EDIPUCRS, 2006.

QUESSADA, Dominique. O poder da publicidade na sociedade consumida pelas marcas: como a globalização impõe produtos, sonhos e ilusões. São Paulo: Futura, 2003.

ROCHA, Everardo P. Guimarães. Culpa e prazer: imagens do consumo na cultura de massa. Comunicação, mídia e consumo, São Paulo, v. 2, n. 3, mar. 2005.

TAVARES, Fred. Discurso publicitário e consumo: uma análise crítica. Rio de Janeiro: E-papers Serviços Editoriais Ltda., 2005. 


\section{Do banco escolar para toda uma vida}

\section{As mudanças no ensino e na escola não se limitam à melhoria na aprendizagem do aluno, mas têm a dimensão ética, voltada para a transformação pessoal e social.}

Mito se discute sobre a necessidade de se mudar as práticas de ensino no Brasil de forma que favoreçam a apropriação de ferramentas teóricas e metodológicas úteis na vida profissional e pessoal, superando os baixos índices de aproveitamento que comprometem a inclusão do aluno na sociedade adulta. Entretanto, as mudanças mais difíceis dizem respeito à transformação das práticas características das relações sociopedagógicas tradicionais: dominação/subordinação, competitividade e individualismo.

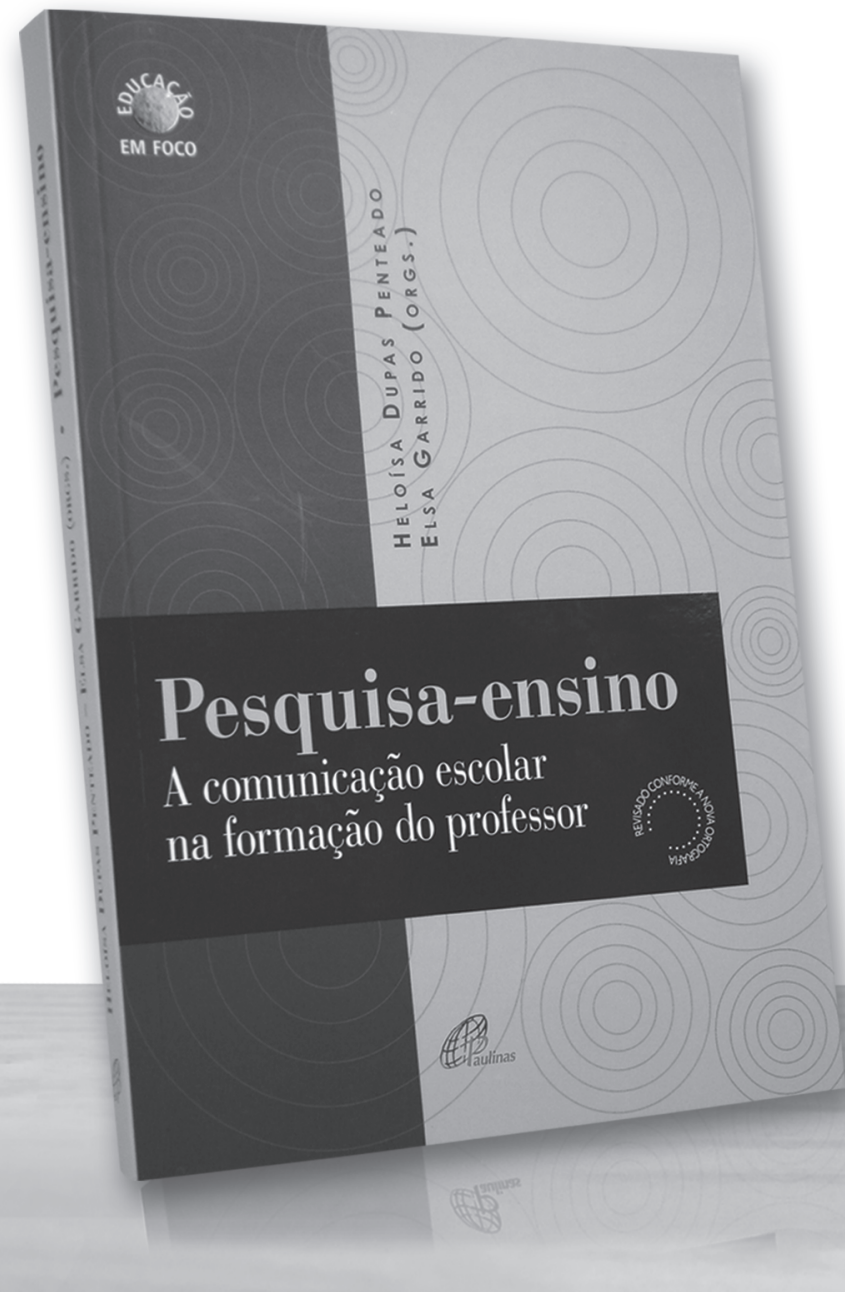

Grupo de especialistas vinculado ao CNPq (Conselho Nacional de Desenvolvimento Científico e Tecnológico) discute o valor da pesquisa-ensino, capaz de fazer da escola espaço de comunicação e cidadania. Defende que a cultura midiática, inserida nos processos de ensino-aprendizagem, se volte para a qualificação e formação do indivíduo, afinal, enquanto processo comunicacional, a educação escolar, mesmo sem suporte, inevitavelmente, entra em contato com essas mídias tecnológicas.

Na verdade, os artigos são um convite aos professores para que superem o isolamento e se associem a grupos de estudo e pesquisa "com o intuito de pensar suas práticas, partilhar questionamentos e experiências, analisar e compreender as relações dos alunos com o conhecimento e as dificuldades que esse lhes apresentam, para transformar sua atividade profissional em atividade de pesquisa reflexiva e criadora".

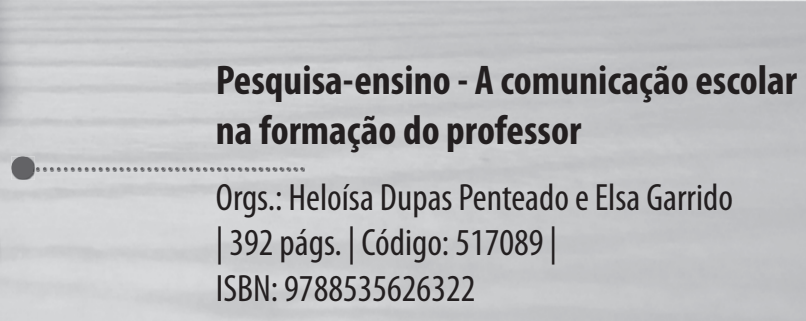

À venda na Rede Paulinas de Livrarias Se preferir, ligue 08007010081 ou acesse www.paulinas.org.br/loja 